\title{
The Influence of Strategic Marketing Practices on Deposit Money Banks Profitability in Nigeria
}

\author{
Onu, Christopher ${ }^{1}(\mathrm{PhD})$, Akinlabi, Babatunde ${ }^{1}(\mathrm{PhD})$, Professor Bakare Ganiyu B ${ }^{2 .}$ \\ ${ }^{I}$ Department of Business Administration \& Marketing, Babcock University, Ilishan Remo Ogun State, Nigeria \\ ${ }^{2}$ Adeleke University Ede, Osun State, Nigeria.
}

*Corresponding Author: Onu, Christopher, Department of Business Administration \& Marketing, Babcock University, Ilishan Remo Ogun State, Nigeria

\begin{abstract}
Strategic marketing is inevitably a survival strategy among organizations (like the Nigerian banking sector) to promote profitability in nation's dynamic business environment. However, without engaging effective strategic marketing in the banking sector, there may be little progress in the Nigerian economy as well as in its banking operations. The purpose of this study was to establish the influence strategic marketing on the profitability of deposit money banks in Nigeria. The research adopted in this study was descriptive survey design. The population of the study was 100 staff of selected banks in Nigeria. Primary data were collected using structured and validated questionnaire. The reliability of the instrument was determined by Cronbach alpha test which were 0.957 and 0.967. The study used descriptive and inferential statistics to analyze the data collected. The particular inferential statistics was regression analysis. Data were analyzed by Statistical Package for Social Sciences version 19.0. The result obtained from the analysis showed that there was a statistically significant influence of strategic marketing practices on the profitability in chosen Nigerian banks. The researchers recommended that deposit money banks in Nigeria need to be consistently and strategically fashioned to start positive change to take advantage of the information and communication technology (ICT) to optimize opportunities in the industry to achieve and sustain competitive advantage both within and outside the shores of Nigeria. The researchers conclude that to promote profitability and survival of the industry, the banking sector should embrace strategic marketing by being focused to adapt to changes, marketing of assets and capabilities, and marketing of innovation.
\end{abstract}

Keywords: Strategic Marketing, Profitability, Marketing Mix, Merger and Acquisition, Deposit Money Banks, Nigeria

\section{INTRODUCTION}

\subsection{Background to the Study}

Nigeria is one of the developing countries in the world, and as such, banking institutions serve as the backbones of the country's financial system and act as catalytic agents in the development process of a country's economy (Oladejo\&Oladipupo, 2011).Also banking institutions intermediate (i.e. provides individuals, government, and businesses financial services) between surplus and deficit spending and increase a quantum (i.e. part or portion) of country's investment, their performance directly affects the efficiency, growth, and stability of the economy (Popoola, 2000; Oladejo\&Oladipupo, 2011). Additionally, Ezeoha (2007) opined that the traditional banking system began in Nigeria in 1952.From that time, the Nigerian banking industry has witnessed moderate growth both in the structure and size. However, the distress that subsequently affected the Nigerian banking sector revealed it was not market-focused in order to meet the challenges in the dynamic environment triggered by unprecedented changes in information technology, consumer expectations, and government regulatory authority policy (Ezeoha, 2007).

According to Ezeoha (2005) "Marketing is the creation and delivery of services to satisfy the customers need at a profit to the bank" (p.3) This definition signifies that customers should be the focus in terms of corporate planning and the survival of banks and therefore, the relevance of marketing to the survival of banking services should be esteemed. In Nigeria, banking was said to have started with the exclusion of marketing like in most developed countries (Ezeoha, 2005). He stated further that the activities were concentrated mainly on acceptance of deposits and lending. The 
industry was controlled by a few banks, and with a seller market, there was no need to spend scarce resources on marketing (Ezeoha, 2005). For the Nigerian banking industry to grow efficiently and be stable, the industry needed to be regulated as well as supervised by the regulatory authorities. This was to enable it to play an active role in the Nigerian economy at regional and global levels, enhanced efficiency, stability, and soundness of the system so as to be competent and competitive players in Africa and at world levels (Soludo, 2004). This initiative (i.e. restructuring through merger and acquisitions as a result of capital inadequacy) was surely confronted with some challenges of liberalization and globalization as a result of technological advancement (Oladejo\&Oladipupo, 2011).

The researchers' submission is that Soludo's (2004) recapitalization exercise was necessary for the growth, as well as for the survival, of the Nigerian the banking sector. However, a low capital base could not be absolutely regarded as the main cause of bank failure in Nigeria before the recapitalization policy in 2004. This is because some developing countries in the world, especially on the African continent have a low capital base, compared to Nigeria and, were still surviving. The researcher thus argues that corruption among bank officials was responsible for the banks' failure in Nigeria. Furthermore, many banks in Nigeria ignored strategic marketing in their banking operations (Akinyele, 2010). Strategic marketing has a pivot role to play in the Nigerian economy, as well as the banking sector. This research therefore emphasizes that strategic marketing in the Nigerian banking sector empowers the management to achieve its marketing programs of merger and acquisition. Strategic marketing is inevitably a survival strategy among organizations (like the Nigerian banking sector) to enable it reap more benefits of recapitalization exercise in this dynamic environment. For any bank to survive in this competitive environment there is the need to adopt effective strategic marketing in the marketing of its services to woo potential customers by satisfying their needs and wants. Moreover, the researchers emphasize that it is through efficient strategic marketing efforts that a developing country like Nigeria can compete efficiently in its banking operations with advanced nations of the world.

\subsection{Statement of the Problem}

Banks are known to be the linchpin of the economy of any country in the world whether developed or underdeveloped. They are crucial in the provision of monetary intermediation, facilitate investments, and promote economic growth (Donli, 2003). The incessant bank crisis in the Nigerian banking sector had been attributed to a weak capital base, an unreliable and inefficient banking system, an over-reliance on public sector deposits, and a weak corporate governance (Adegbaju \& Olokoyo, 2008; Soludo, 2004). Soludo (2004) expatiated on the above problems by stating that the average capital base of the Nigerian banks is $\$ 10$ million, which is too small when compared to other developing countries in the world like Malaysia; where the least bank has a capital base of \$526 million. Also there is the issue of unreliability and inefficiency in the Nigerian banking system as evidenced on late or non-publication of yearly accounts of banks' performance to the stakeholders to assess banking soundness. In addition, some banks rely on public sector deposits while disregarding small and medium class savers. Thus, when the income from the government is not forthcoming because of the unpredictability of the international oil market, the concerned banks might be weak and likely to liquidate. Finally, some banks have weak corporate governance manifested by a low ethical standard, a low transparency with misleading financial report, managerial incompetence of board members and staff of the banks; and some fraud-related losses that could have been prevented if the banks had sound internal control system (Donli, 2003; Soludo, 2008). To deal with the above problems, there is a need to embrace strategic marketing for the growth, profitability, and customeroriented service for the survival of the Nigerian banking Sector.

\subsection{Research Objective}

The objective of this study was to establish the influence of strategic marketing practices on the profitability of deposit money banks in Nigeria.

\subsection{Hypothesis}

- There is no significant influence of strategic marketing practices on the profitability in chosen Nigerian banks.

- There is a significant influence of strategic marketing practices on the profitability in chosen Nigerian banks. 


\section{LITERATURE REVIEW}

\subsection{Conceptual Framework}

\subsubsection{Strategic Marketing}

Strategic marketing, according to Barney (1991) is "the process whereby individuals or organizations make certain decisions in relations to future results and methods in which they are to be achieved and estimated" (p.27). Therefore, strategic marketing assists managers in formulating, implementing, and evaluating cross functional decisions that will help organization to achieve its objectives. In addition, it is vital for an organization to be knowledgeable about its market, the customers, the competition, and relating it to the product or service of the organization to achieve competitive advantage over its competitors. In the view of Woodward (2004), strategic marketing is a means by which an individual anticipate the future and develop the necessary procedures and operations to influence and achieve the objectives. Strategic marketing allows an organization to be proactive (making things happen rather than waiting for things to happen), rather than reactive (response in shaping its own future). This is not the case in Nigeria, where marketing managers are good in formulating strategic marketing mission, purpose, and objectives for specific activity.

\subsubsection{Merger and Acquisition}

The terms mergers and acquisitions have different meanings. Delta publishing company (2009) defined merger as "where two or more companies are combined into one where only the acquiring company (Larger of the two) retains its identity" (p.2). Acquisition, on the other hand, is the takeover of a whole or part of the target firm by another (Grandin\&Saidane, 2010). Studies conducted by the international labor organization (ILO) revealed that mergers and acquisitions are worldwide event, with approximately 4000 deals taken place annually. There is no doubt that they are not a new phenomenon because five periods of merger and acquisition activity happened in the United States in 1897-1904, 1916-29, 1965-69, 1984-89 and 1993-2000 (ILO, 2001). Additionally, merger and acquisition became conspicuous in the Nigerian banking sector during the banking sector consolidation exercise in 2004/2005 with effect from January 1, 2006 under the Central Bank Nigeria (CBN) Governor known as Professor Charles ChukwumaSoludo. As at June 2004, Nigeria had 89 banks with 338 branches in various cities and villages (Soludo, 2004). In addition, the branches were characterized by operational and structural weaknesses in the areas of a low capital base, a weak corporate governance, an insolvency, a long customers queue in the banking hall due to poor infrastructure and technology, dominance of few banks, a low depositors' confidence and an overdependence of public sector deposits (Soludo, 2004).

On assumption of office in 2004, Charles ChukwumaSoludo employed merger and acquisition as an intervention strategy to save the Nigerian Banking Sector from total collapse and thus reposition the Nigeria financial system for the $21^{\text {st }}$ Century. This move led to merger and acquisition by Nigerian banks, and thus resulted in reducing the number of the Nigerian banks from 89 to 25 banks by December 31, 2005. Although, the Nigeria banking sector regulator; Central bank of Nigeria (CBN) employed merger and acquisition as an instrument to affect structural and operational weaknesses in the Nigerian banking sector in 2004-2005. However, OghojaforandAdebisi (2012) suggested that merger and acquisition as a strategic tool must be carefully applied and implemented in the banking system. They advised the Central bank of Nigeria (CBN), as well as the other regulatory agencies, to be cautious in hastily going to another forced merger and acquisition by making sure that the balance sheets are not exhibiting misleading or falsified figures that will mislead the investors. In the same vein, Oluyemi (2006) stressed that even though the numbers of banks have reduced drastically as a result of merger and acquisition, the need to cope with new mega banks require more monitoring and supervision by the regulatory authorities. On the contrary, Ogunleye (2005) argued that merger and acquisition in the areas of capital base of 25 billion naira will do more harm than good to the banking industry and stressed some of the problems to be experienced in terms of overcrowding of the sector, mass unemployment, unethical practices such as money laundering, and disregard to micro lending to small scale businesses required for growth of the economy.

Additionally, Havakimian and Kane (2000) conducted studies between 1985 and 1994 in the United States to determine the impact of using capital requirements to control risk shifting in a sample of 123 United States banks. Risk shifting occurs when guarantors or creditors are exposed to loss without 
giving adequate compensation. They found that an average capital regulation was not a hindrance to sample banks from shifting risk to the safety net. Risk shifting was ascertained to be strong for low capitalized banks and banks having high ratios of ensured deposits to insured debt.

Also, some researchers have made some suggestions and criticisms on merger and acquisition in the Nigerian banking industry. The essence of merger and acquisition in any organization is the desire to increase the return on equity (leverage), not to escape liquidation or comply with some statutory requirements of the government. Hence, the views of the enumerated researchers (Oghojafor\&Adebisi, 2012; Oluyemi, 2006) are necessary to reflect about the enhancement the quality of banks, establishing financial stability and ensuring the banking sector contributes to the economy of Nigeria as well as in global level.

Furthermore, Aminu (2006) argues that banks need not to be compelled to engage into merger and acquisition. This view is interesting but not applicable in all circumstances. When there is the desire to increase the return on equity, voluntary merger and acquisition is necessary. Also when there is insiders' abuse and bad financial management, as were responsible for the weaknesses of the 89 banks in Nigeria prior to 2004, the only option available in that circumstance was forced merger and acquisition that was required for the stability of the banking system.

Ogunleye (2005) accentuated that merger and acquisition will lead to congestion of the banking sector, joblessness, and unethical practices. However, the researcher argues that merger and acquisition may not likely lead to congestion, unemployment, and unethical practices. Congestion will not be experienced in the sector since the banking halls of the different banks will still be operational after merger and acquisition. Unemployment may not likely be experienced and even if it will occur, it may affect unproductive employees, but deployment may be visible. Unethical practices will not be experienced because regulatory authorities will cautiously apply and implement the program to ensure that the gain from merger and acquisition is sustained.

\subsubsection{Marketing Mix}

The application of marketing principles in the rendering of banking services is optimally achieved via the marketing mix (or ingredients). Ojo (2012) opined that an effective marketing mix will guarantee better performance in banking sector. The concept of marketing mix was popularized by Kotler \& Armstrong (2006), and it consists of a set of controllable (micro) variables that a firm uses to influence the target market. Kotler \& Armstrong (2006) opines that firm's marketing Mix is "the set of controllable tactical marketing tools- product, price, place, and promotion- that the firm blends to produce the response it wants in the target market" (p.50). The marketing decisions made by managers while configuring their offerings to suit consumers' needs generally divided into four controllable elements: product, price, place, and promotion, known as marketing mix. These are the marketing activities a firm can control and marketing managers decide which of the element to use and in what amount to meet the needs of customers within its target market (i.e. a specific group of customers on whom an organization focuses its marketing efforts). In a 1964 study, McCarthy (as cited in Goi, 2009) popularized these elements as 4Ps of marketing. Borden (1965), however, claimed to be the first to have used the term "marketing mix" from Culliton's 1948 explanation of the business executive as "a mixer of ingredients, who sometimes follows a recipe as he goes along, sometimes adapts a recipe to the ingredients immediately available, and sometimes experiment with or invents ingredients no one else has tried" (cited in Goi, 2009, p. 2).The 4Ps are the parameters under the control of the marketing manager, subject to the internal and external constraints of the marketing environment (Borden, 1965). These variables do not work individually but interrelated, and any marketing decision taken in one area of the four components will affect action in the other areas.

The traditional marketing mix known as the 4Ps of marketing, i.e., product, price, place, and promotion as shown in Figure1 above (left hand side), have been operational for a long time and applicable in the manufacturing industry (tangible goods). However, it seems that the traditional marketing mix is irrelevant in the context of service differentiation because of the increasingly growth of marketing of services. As a result, Booms and Bitner (1981) expanded the concept of the marketing mix by including three additional Ps (3Ps) of marketing as also shown above (right hand side), and thus extending it to 7Ps applicable especially, in service environment as indicated in the figure above. The new 3Ps are referred to as people, process, and physical evidence (or presentation). To develop service quality, the above three elements need to be considered especially, in financial service 
marketing. To affirm the relevance of the 3Ps in service sectors, especially in the banking sector, Kotler, Wong, Saunders \& Armstrong (2005) reiterated that banking transactions are known to be invisible because remitting of fund from one account to another cannot be seen and as such very difficult to assess. Therefore, banks have to be concerned with making themselves remarkable for more conspicuous offerings (which could be referred to as process, physical evidence).

Basically, the marketing mix variables are crucial tools an organization could use in developing its long-term marketing strategies as well as short-term tactical program. It is the duty of the marketing manager to develop and to make amendments on the marketing mix so as to satisfy the needs and wants of customers. Ojo (2012) opined that an effective marketing mix would guarantee better performance in the banking sector. Therefore, the Nigerian banking sector needs marketing mix inputs to ensure it achieves efficiency in its strategic marketing approach (or long-term marketing strategies). Therefore, the Nigerian banking sector needs marketing mix inputs to ensure it achieves efficiency and effectiveness in its strategic marketing approach (or long-term marketing strategies).

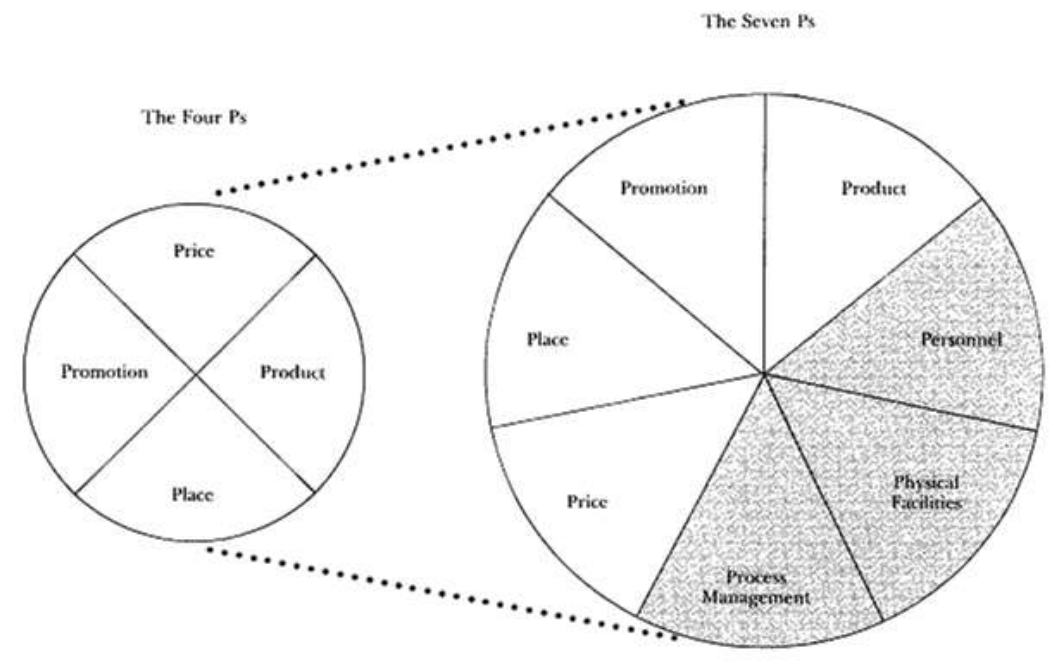

Figure1. Extension of 4Ps to 7Ps services marketing framework

Adapted from when marketing services, 4Ps are not enough by A.J. Magrath, 1986. Business Horizons.

\subsubsection{Profitability}

The word profitability has two words, namely, profit and ability. By profit, it means income generation and the term ability indicates the power of an organisation to earn profits. Profitability is defined as the ability of a given investment to earn a return from its use. Profitability is a condition in which the income realized at a given period greater the expenses incurred over the same period of time for the only aim of getting an income (Sanni 2006, as cited in Aremu, Ekpo, \& Mustapha, 2013). They stated further that three indicators of profitability are Return on Equity (ROE), Return on Assets (ROA), and Net Interest Margin (NIM). Arun and Sal (2010) studied the role of profit in influencing the growth of firms. Besides, they found that greater profit may assist a firm to grow faster. This implies that profit provides money for growth that may be internally through investment in development projects or grow in merger and acquisitions through possessions of internal funds that facilitate an organization to engage on growth projects. According to Albrecht, (2011), profitability is often determined when those costs are placed against revenue, which have contribution in the generation of such revenue. Weston and Brigham (1990) regarded profitability as the net surplus after the deduction of all charges from all the activities or policies and decisions of a business enterprise. It can be measured with return on investment position relative to competition, satisfaction with income on sales, satisfaction with income on organizational investment, satisfaction with return on sales, net profit position relative to competition and financial liquidity position relative to competition. Recent literature analyzes the profitability of companies from various countries and economy sectors through indicators like net operating profitability (NOP) as identified by (Rahemanet al., 2010), (Dong \& Su., 2010), return on total assets (ROTA) (Deloof, 2003), (Padachi, 2006), return on invested capital (ROIC), return on assets (ROA) (Narware, 2010). In these cases, the elements considered by profitability analysis are financial indicators that express the strategic marketing of banks. 


\subsection{Theoretical Framework}

\subsubsection{Theories of value formation}

The theories of value formation or strategic business behaviors were established in dealing with globalization in the Nigerian banking sector. These theories are convergence, divergence, crossvergence, and transvergence of value formations. The researchers' submission is that globalization is a gradual disappearing of national borders between nations or among nations as means of global integration and spreading of universal benefits among individuals in the globe. Considering organization and management practices expanding globally, managers from various organizations are confronted with the challenges of modifications of business practices and values in culturally and technologically manner. Culture has become important in shaping management practices in form of convergence, divergence, crossvergence, and transvergence. In discussing convergence theory, Weber (1969) highlighted that people from advanced countries, in spite of the economic advancement will form attitudes and behaviors consonant with technology of their society. Ralston (2008) in support of divergence theorists believed that cultural values will make individuals from a society cherish and appreciate particular desirable value through time, in spites of technological and economic believes as well as political change. Therefore, Ralston, Holt, Terpstra \& Dalian (1997) proposed another view that merges convergence and divergence known as crossvergence. Crossvergence theory supports the interaction of socio-cultural and business believes influences for the formation of recent and very special believes among people in a society. It is vital to discuss each of the value systems debates, the contributors, and their views in details to explain strategic perspectives for interpreting globalization in the Nigerian banking industry. The rationale for discussing these theories is to assist the Nigerian banking sector to "think globally but act locally." This implies the management of the Nigerian banking sector needs to study these management values from advanced nations of the world, and in terms of its applicability; they will need some amendments or improvement programs when applying in local environment or different cultural environment. To withstand this global competition, it becomes imperative for the Nigerian banks to endeavor to expand their operations by embracing strategic marketing in their structure and strategy.

\subsection{Empirical Review}

Ojo (2011) conducted a study on the effective marketing strategies and the Nigerian construction professionals. The study examined the existing marketing strategies with the aim of determining their level of usage and effectiveness among Nigerian construction professionals. Six marketing strategies were identified for assessment by the consultants and contractors. These were location of firm, promotion, professional - client relationship, professional contract, marketing mix (4ps) and research. The result of the data analysis indicated that the level of awareness of marketing strategy is low among the construction professionals surveyed despite the fact that they believed it is very essential in improving productivity. Professional- client relationship and professional contract were ranked very high as popular and effective marketing strategies.

Danjuma, Audu, and Omaku (2014) carried out a study on the evaluation of marketing strategies undertaken by Coca Cola Company as a multinational corporation in Nigeria. The four (4) basic marketing strategies which are commonly called the $4 \mathrm{ps}$ which denote price, product, promotion and place are exceedingly used by Coca Cola Company in Nigeria. The findings revealed that Coca Cola Company strategy of sales was price penetration where low price are charged and the company attends large market as possible. Unlike price skimming where higher price are charged. Product strategy was strongly applied such as the modification of its product as well as after sales services which all help to facilitate the marketing of the product. Promotion strategy which includes the sales promotion, technological change and advertisement were all used by coca cola Company in the marketing of its product in Nigeria. Finally, place strategy which involves selection of distribution channels, transport arrangement and so on which are very essential to the corporation was used.

Ayedun, Oloyede, Oluwunmi and Oyedele (2014) conducted a research on the effect of marketing strategies on corporate performance of estate surveying and valuation firms in Kaduna Metropolis of Nigeria. Using structured questionnaires administered on estate surveying firms operating within the metropolis subsequently analyzed with the aid of simple statistical techniques, the finding revealed that there is a positive relationship between marketing strategies adopted (that is, hanging of "To Let" boards, bulletin/handouts, newspaper advertisements, personal contacts, property magazines, and internets) and corporate performance of the firms. 
Chiliya, Herbst and Robert-Lombard (2009) carried out a study on the impact of marketing strategies on profitability of small grocery shops in South African township. Primary data were used to sample 36 grocery shops and the study employed regression method of analysis. The study established that marketing strategies significantly improve small grocery shops in South African.

Bello and Aina (2015) investigated the role of marketing research on the performance of business organisations. The study was conducted in federal capitalterritory, Abuja, North-central Nigeria with the use questionnaire and interview to collect data that wasstatistically analyzed using Pearson Correlation Method of analysis. The study found that marketing research process plays a significant role in the performance of business organisations which meansthat there is a positive relationship between marketing research and the performance of business organisations.

Oseyomon and Gbandi (2014) in their work on Market orientation and profitability of quoted companies in Nigeria. Purposive sampling method was used to select a total sample size of fifty (50) companies. Through the techniques of simple random sampling, a total number of two thousand, two hundred and twenty $(2,220)$ customers were selected from the quoted companies. Index and mean index methods were used to measure the level of customer satisfaction. The study revealed a mean index score of 2.3 measured against a scale of 5. This implied that the extent of customer satisfaction was below average.

Oloko, Anene, Kiara, Kathambi and Mutulu (2014) in a study on marketing strategies for profitability. The study basically used a textual approach in collecting and analyzing data which was presented in content and thematic analysis from secondary data. The scope of the study was the Safaricom limited company. The study found various marketing mix and techniques were employed that include: auditory marketing, new product creation, animation, pricing, place, content localization, brand alliances, use of celebrities and constant promotions. The study indicates that these techniques were found to enhance the uptake of Safaricom products hence, resulting to increased revenue leading to profitability.

Jenkins (2015) examined a study titled "marketing strategies for profitability in small independent restaurant. Data collected from interviews and archival business records and the data were analyzed using regression method of analysis. Five marketing strategy themes emerged from the study: word of mouth and social media marketing limited financial resources, product differentiation and atmosphere, blogging and using the point of sale (POS) system, and employee engagement and upselling. Participants stated that word of mouth and social media marketing were powerful strategies that small independent restaurant owners should use to retain customers and gain new customers.

\subsection{Strategic Marketing and Profitability}

Positioning for growth and profitability are inseparable because one cannot be discussed without the other. Growth is measured in relation to deposits growth position relative to competition, satisfaction with deposits growth rate, and market share gains relative to competition (Oyedijo, 2004). Profitability is a condition in which the income realized at a given period greater the expenses incurred over the same period of time for the only aim of getting an income (Sanni2006, as cited in Aremu, Ekpo, Mustapha, 2013). They stated further the three indicators of profitability as Return on Equity (ROE), Return on Assets (ROA), and Net Interest Margin (NIM).Arun\& Sal (2010) studied the role of profit in influencing the growth of firms. They discovered that greater profit might assist a firm to grow faster. This implies that profit provides money for growth that may be internally through investment in development projects or grow in merger and acquisitions through possessions of internal funds that facilitate an organization to engage on growth projects. Additionally, Roy (2010) enumerated three criteria that would enable a bank to grow in profitability that are (1) the bank is where there are possibilities for growth, (2) it is in strategic area to compete as other banks, (3) it has capacity to grow. Strategic marketing practices for growth and profitability need to assess the above criteria and allocate organizational resources for the various business departments of a bank.

Banks are expected to grow in size, acquire better market share and profitability (Scott \&Aria, 2011). To achieve these objectives, it is crucial for a bank to choose and position itself in certain target markets (city, state, country, region, continent, etc), showing the main markets where they are present. After merger and acquisitions in Nigerian banks, it becomes imperative to determine the relative growth and profit potentials for the various markets being served by the Nigerian banking sector. To 
carry on this efficiently, the researchers' employed the BCG Matrix model (Kazmi, 2006) shown in Figure 2 above. Although there are other models that deal with positioning for profitable growth, the BCG matrix model will be used for this research. This is based on banks activities that are parallel or uniform to business units in numerous localities, countries, regions, and continents in which banks carry out their activities as separate entities, but all constitute to market portfolio.

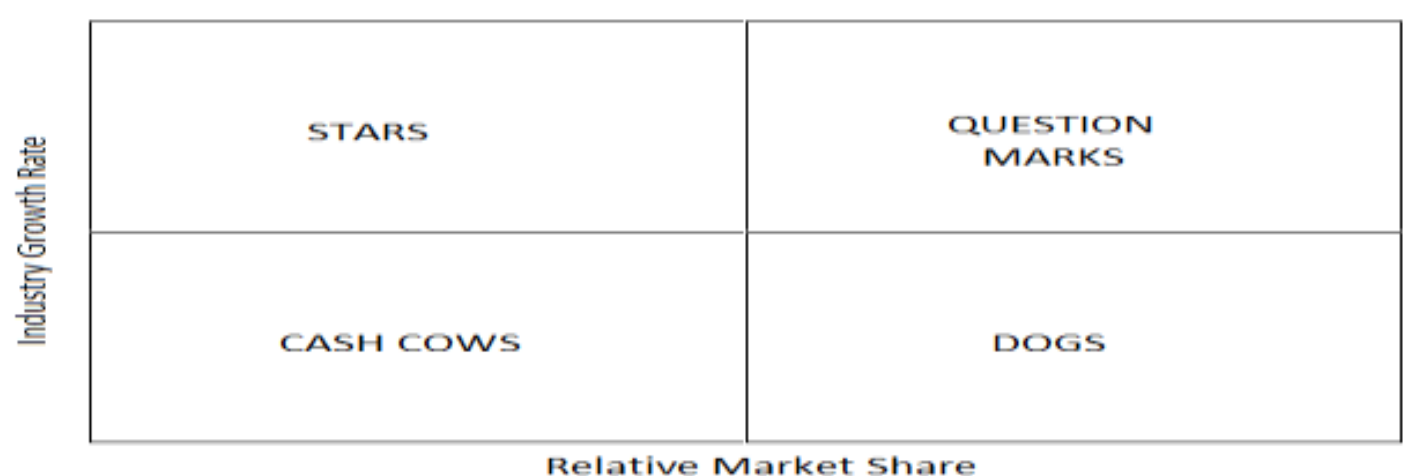

Figure2. Boston Consulting Group (BCG) Matrix Model. Adapted from business policy and strategic management, $2^{\text {nd }}$ edition, by A.Kazmi, 2006.

Moreover, the BCG matrix can be related to the banking industry in the area of relative growth and profit potentials for different markets that a bank serves. The BCG growth share matrix is a model by which banks are classified in relation to market growth and banks relative market share. Oyedijo (2004) opined that the basic idea underlying BCG Matrix is that an organization should have a balance portfolio of businesses whereby some earn more money than they can use, and as such help other businesses within the portfolio that require money for their development and thus becomes profitable. The BCG Matrix, such as the one shown in figure 2 provides a graphical representation for an organization to examine the different businesses in its portfolio on the basis of their relative market shares and industry growth rates. Kazmi (2006) opined that the growth rates of various business units are denoted on the vertical axis of the matrix while the horizontal axis denoted as growth rate showing high or low growth rate. On the other hand, the relative market share of product business has been used for profitability and plotted on the horizontal axis, showing line between low or high market shares. The portfolio of growth markets has been divided into four: stars, cash cows, dogs, and question marks (wildcat or problem child). We shall consider each of these elements as follows:

Stars and Cash Cows: Stars are strategic business unit (SBU) that have a high market share in rapidly growing market but may not be self-sufficient in the area of cash flow. It is the market leader in a high-growth market. Stars are question marks businesses that have become successful. They are often the hope of the future. Stars are often cash using rather than cash-generating (Oyedijo, 2004). Oyedijo (2004) further indicated that they are short-term, priority consumers of corporate resources within the overall business portfolio that need to nurture, maintain their health and waiting for the market growth to show so that cash flows will increase. On the other hand, cash cows are businesses that have high market shares but their rate of growth is slow. In the area of product life cycle (PLC), they are mature businesses that have strong competitive positions in mature industries. Because of their strong position and minimal reinvestments for growth, such businesses often generate cash in excess of their corporate portfolios. The task of manager is to manage and protect cash cows effectively to maintain their strong market share because they generate excess resources for corporatewide use and supply the fund for future growth (Oyedijo, 2004).

Dogs and Question Marks: Dogs are businesses with low market share and low market growth. They are businesses that have been saturated, mature markets with intense competition, and low profit margins. They do not generate or require large amounts of cash. In the area of product life cycle (plc), the dogs are products in the late maturity or declining stage. The experience curve shows that it is confronted with cost disadvantages as a result of low market shares (Kazmi, 2006). Question marks are known as problem children. Question marks are businesses with high industry growth but low market share. They need a huge amount of cash to gain market share. Question marks are strategic business units (SBUs) relatively weak in competitive terms (because they have low relative market shares) but are based on high-growth industries and thus may offer a potential opportunity for longterm growth and profit (Kazmi, 2006). Developing a strategy for question marks means either 
investing large sums in hopes of gaining a viable market or not investing and possibly missing a growth market. Low share of a growing market suggest that considerable net injections of cash are needed to build market share (Oyedijo, 2004).

In applying BCG Matrix in banking sector, bank branches have been divided into four quadrants, namely: stars, sleepers, question marks, and dogs (Roy, 2010). The units in the star quadrants are benchmarks for better operating practice while sleepers are units that are profitable but inefficient. These units face a better business environment but have the potential for improvement. Question marks have the capability for higher profitability and efficiency, and dogs are the bank branches carrying its activities efficiently with a low profit because of unfavorable business environment.

As stated earlier on, banks carry out their activities in different business units at various localities, regions, and continents independently, but together make up its market portfolio. The financial requirement of households and markets for loans and deposit shows life cycle attitude as a result of variations in income, competition, and demography from increased to maturity, and saturation. Initial branches usually being faced with inactivity and at the same time new branches dealing with present generation customers with technology-based services may grow fast (Roy, 2010).

Moreover, as seen from the above description of the BCG matrix model in the banking sector, it is clear that it has many forthcoming. Oyedijo (2004) specified the benefits of BCG matrix as it assists in providing assistance in directing investment across branches of the banking sector, and it offers a simple but useful guideline for checking for consistency among branches of the banking sector. Also Kazmi (2006) stated that high market share may not bring high profits because high costs also involved in the high market share, and the growth rate and the relative market share are part of the indicators of profitability (same as in the banking sector). The model disregards other indicators of profitability in the banking sector. However, there are some limitations that arise from the assumptions on which the BCG matrix is based. Also Armstrong and Brodie (1994), as cited in Roy (2010) have stressed that the use of BCG matrix may result to choosing of businesses and projects less productive. It is evident from the researchers' submission that the foregoing criticism of the BCG (Boston consulting group) matrix model planning technique does not mean that such technique should not be used in the banking sector. What is suggested is that it should be used with caution.

\section{MeThodology}

\subsection{Research Design}

This study adopted descriptive survey research to investigate strategic marketing quantitative study of the Nigerian banking Sector. This research design was considered because it would allow for collection of quantitative or numeric data to be analyzed numerically using descriptive and inferential statistics. The researcher made use of descriptive survey research to gather opinions regarding past and present marketing strategies via a questionnaire.

\subsection{Study Population}

The scope of the study covered five (5) deposit money banks with headquarters in Lagos State. The population of study consisted of staff in corporate planning department, commercial department, and marketing department of five (5) sampled deposit money banks in Nigeria which have their headquarters in Lagos State. According to the human resources department of the five selected banks revealed that: First Bank has 33 staff, Zenith Bank has 31 staff, Guaranty Trust Bank has 27 staff, United Bank for Africa has 26 staff and Wema Bank has 21 staff (Human resources department-First Bank, Zenith Bank, Guaranty Trust Bank, UBA \&Wema Bank, 2013). Therefore, the total population of staff of the three departments of the five selected banks for the study was 134 .

\subsection{Sample Size and Sampling Technique}

The sample size for this study was determined using the formula for sample determination for a finite population as expressed by Yamane (1973).A sample size of 100 (20 to each bank) staff was selected using stratified sampling and convenience sampling techniques. The basis for chosen 20 respondents each from the five selected banks is to ensure equal representation. In addition, the sampling techniques employed in this study are probability sampling technique (stratified sampling) and nonprobability sampling (convenience sampling) (Asika, 2004). The researchers were interested in observing what was happening at corporate planning department, commercial department, and 
marketing department of the selected banks and without any attempt to manipulate or control it.A single-stage sampling procedure was used by the researchers, through the assistance of the Human Resource departments of the selected banks.

\subsection{Instrument for Data Collection}

A self-developed structured questionnaire was used to collect data. The questionnaire was divided into three sections. The first section of the survey instrument contained items that addressed demographical information of the respondents. In Section 2, there were five items that addressed the questions related to the extent to which strategic marketing has affected the Nigerian banking industry. In Section 3, there were six items that addressed profitability in the Nigerian banking sector. Section 1 consisted of closed-ended questions. Section 2 and 3 used a structured 5 points likert scale battery of strongly agree (5), agree (4), neutral (3), disagree (2), and strongly disagree (1) in line with Atiku, Genty and Akinlabi (2011). The participants were asked to indicate agreement or disagreements with various statements. In this study profitability was assessed by financial liquidity position relative to competitors; return on investment and net profit positions relative to competitors, and satisfaction with return on sales and corporate investment relative to competitors (Weston \& Brigham, 1990). For the analyses and data interpretation, strongly agree was condensed to agree and strongly disagree was collapsed to disagree. This was done to enable easier analysis.

\subsection{Validity and Reliability of the Instrument}

The validity of questionnaire was evaluated by experts in banking to ensure that the developed questionnaire had included all the important questions needed to facilitate excellent study about strategic marketing quantitative study in the Nigerian banking industry. Also, two senior academics in the field of marketing from department of Business Administration and Marketing, Babcock University, Ilishan-Remo, Ogun State validated the instrument. According to Brown et al. (1992), validity of an instrument is better improved by expert judgments. Also to test the reliability, the researchers conducted a pre-test of the instrument with Ecobank staff in Lagos State, Nigeria, which was not being part of respondents. The aim was to discover if the instrument would obtain information required or would show unreliable information in response to the questions that were developed and presented to the respondents. Twenty (20) questionnaires (the basis for chosen 20 samples each from the five selected banks is to ensure equal representation from each of the banks) were self-administered to the Ecobank staff. All the questionnaires were filled and returned to the researcher within two (2) days. A total of 20 questionnaires (100\% response rate) were processed and analyzed to test the reliability of the instrument. This was presented in Cronbach's Alpha that is a measure of internal consistency, which is, how closely related a set of items are regarded as a group. Sekaran \& Bougie (2010) proposed that Cronbach alpha coefficient is the most popular test being used to measure internal consistency reliability of a measuring instrument in research. From the analysis, the instrument's reliability coefficients (Cronbach Alpha) were: Strategic marketing was 0.957, and Profitability was 0.967. All the variables met Nunnally (1978) internal consistency (reliability) benchmark for Cronbach's Alpha Score of 0.7 .

\subsection{Method of Data Analysis}

Data analysis in this research work involved the quantitative data that emanated from the questionnaire administered. The statistical package for social science (SPSS version 19) was used for analyzing the quantitative data. The data collected were edited, appropriately coded, the data files checked and re-checked to minimize data entry errors and detect out-of-range values that were rectified before analysis. Descriptive statistics such as frequency, percentages, mean, and standard deviation were used for describing observations made. A simple regression model was utilized to analyse the data and expresses the relationship between one dependent variable (usually denoted by Y) and a series of other changing variables (known as independent variables). The proposed regression model is described as follows:

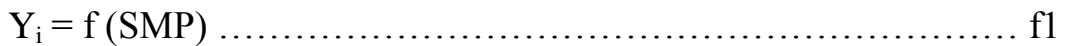

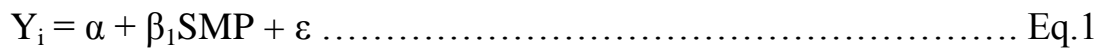

Where:

$\mathrm{Y}_{\mathrm{i}}$ is Profitability (Dependent variable).

ais Constant term 
$\beta_{1}$ is Coefficient of Strategic Marketing Practices

SMP is Strategic Marketing Practices (Independent variable)

cis the Error term or Stochastic variable

\section{Presentation And Interpretation Of Data}

\subsection{Socio-Demographic Profile of the Respondents}

Table 1 shows results of the socio-demographic characteristics of the respondents. The results in the table indicate that $60 \%$ of the respondents were male while a sizeable percentage of $40 \%$ were female. Majority (51\%) of the respondents fall under the age group categories of 31-40 years while only $14 \%$ were between 40 to 50 years, which could mean that majority of the respondents in the sampled commercial banks are in their middle ages and this age usually constitute the vibrant cream of the workforce in the private organizations. With regard to educational qualification, majority (52\%) of the respondents had attained master's degree, followed by bachelor degree $(39 \%), 3 \%$ had doctorate degree, $6 \%$ had professional qualification while only $1 \%$ had other qualifications. This could mean that most of them have attained secondary degree in relevant qualifications to help analyze issues.

Table1. Socio-demographic characteristics of the respondents

\begin{tabular}{|c|c|c|}
\hline Variables & Frequencies & Percentages \\
\hline \multicolumn{3}{|c|}{ Gender } \\
\hline Male & 40 & 40 \\
\hline Female & 60 & 60 \\
\hline Total & 100 & 100 \\
\hline \multicolumn{3}{|c|}{ Age } \\
\hline $20-30$ & 35 & 35 \\
\hline $31-40$ & 51 & 51 \\
\hline $41-50$ & 14 & 14 \\
\hline Total & 100 & 100 \\
\hline \multicolumn{3}{|c|}{ Educational Qualification } \\
\hline Bachelor Degree & 39 & 39 \\
\hline Master Degree & 52 & 52 \\
\hline Doctorate Degree & 3 & 3 \\
\hline Professional & 6 & 6 \\
\hline Others & 1 & 1 \\
\hline Total & 100 & 100 \\
\hline \multicolumn{3}{|c|}{ Banks } \\
\hline First Bank & 20 & 20 \\
\hline Zenith Bank & 20 & 20 \\
\hline Guaranty Bank & 20 & 20 \\
\hline United Bank for Africa & 20 & 20 \\
\hline Wema Bank & 20 & 20 \\
\hline Total & & \\
\hline \multicolumn{3}{|c|}{ Departments } \\
\hline Planning & 12 & 12 \\
\hline Commercial & 30 & 30 \\
\hline Marketing & 40 & 40 \\
\hline Others & 18 & 18 \\
\hline Total & 100 & 100 \\
\hline \multicolumn{3}{|c|}{ Positions } \\
\hline Top Manager & 16 & 16 \\
\hline Middle Manager & 38 & 38 \\
\hline Lower Manager & 44 & 44 \\
\hline Others & 2 & 2 \\
\hline Total & 100 & 100 \\
\hline \multicolumn{3}{|c|}{ Length of Service } \\
\hline Less than 1 year & 8 & 8 \\
\hline $1-5$ years & 41 & 41 \\
\hline $6-10$ years & 24 & 24 \\
\hline 11-15 years & 18 & 18 \\
\hline Above 15 years & 9 & 9 \\
\hline Total & 100 & 100 \\
\hline
\end{tabular}

Source: Field Survey, 2015 
In respect of departments wherein respondents are working at the time of survey, the largest number (40\%) of respondents work in marketing department, followed by commercial department $(30 \%)$, $18 \%$ of respondents work in functional areas other than marketing, commercial, and corporate planning departments while $12 \%$ of the respondents' works in corporate planning department. It could be deduced from the data analyzed above that the marketing department and commercial credit departments have the higher number of staff as such the bank will always strive to gain the larger share of market share. The employment status indicate that, majority $(44 \%)$ of the respondents worked as lower managers, followed by respondents who are middle managers (38\%) and top managers accounted for $16 \%$ while other options made available in the question attracted only $2 \%$.

With regard to the duration of employment, $92 \%$ of the respondents had worked in the commercial banks for a period of 5 years and above which implies the respondents have considerable experience in their fields that will enable them to have a good knowledge of strategic marketing practices of commercial banks.

\subsection{Mean and standard deviations of Strategic Marketing Practices}

The result of mean and standard deviation of strategic management practice are in table 2.Table 2 below indicates the means, standard deviations, and mean ranking of the strategic marketing practice dimensions. Mean scores above 3.0 indicate that respondents are more likely to be satisfied with strategic marketing practice and was rated very high, while mean scores below 3.0 indicate that respondents are more likely to be dissatisfied with strategic marketing practice and was rated very low. The variables were ranked using the mean score to determine the independent variable that is highly emphasized by the respondents. According to table 9 below, the mean score for strategic marketing is a policy for your bank (4.4600) was the highest in comparison to the other strategic marketing practice dimensions.

Table2. The Mean and Standard Deviation of the Dimensions of Strategic Marketing Practice

\begin{tabular}{|l|l|l|l|l|}
\hline \multicolumn{1}{|c|}{ Strategic marketing practices variables } & $\begin{array}{c}\text { Total score } \\
\sum \mathbf{X}\end{array}$ & $\begin{array}{l}\text { Mean Score } \\
X\end{array}$ & $\begin{array}{c}\text { Standard } \\
\text { deviation }\end{array}$ & Rank \\
\hline Strategic Marketing is a policy for your bank & 446 & 4.4600 & .71661 & $1^{\text {st }}$ \\
\hline $\begin{array}{l}\text { Strategic Marketing is a necessity for survival in the } \\
\text { present merger and acquisition in Nigerian banking } \\
\text { sector }\end{array}$ & 443 & 4.4300 & .62369 & $3^{\text {rd }}$ \\
\hline $\begin{array}{l}\text { Your bank presently facing strong competition from } \\
\text { other banks }\end{array}$ & 444 & 4.4400 & .65628 & $2^{\text {nd }}$ \\
\hline $\begin{array}{l}\text { The competition affects strategic marketing adopted } \\
\text { by your bank }\end{array}$ & 404 & .0400 & .65185 & $5^{\text {th }}$ \\
\hline $\begin{array}{l}\text { Through strategic marketing, your bank has the } \\
\text { capability to react to competiveness both local and } \\
\text { globally after consolidation of the banking sector in } \\
\text { 2006 compared to competitors }\end{array}$ & & & \\
\hline
\end{tabular}

\section{Source: Field Survey, 2015}

The standard deviation was 0.71661 . It could therefore be inferred that the respondents were mostly satisfied with the strategic marketing policy put in place in their organizations. However, the standard deviation indicated that some respondents possibly perceived the strategic marketing policy differently. The mean score for the banks are presently facing strong competition from other banks was the next in the rank with a mean of 4.4400 and the standard deviation was .65628 . This meant that most of the respondents were aware about strong competition facing their organizations from other banks. According to Table 2, the mean score for strategic marketing is a necessity for survival in the present merger and acquisition in the Nigerian banking sector was 4.4300 and the standard deviation was .62369. This therefore indicated that the respondents were agreed that strategic marketing is a necessity for survival in the present merger and acquisition in the Nigerian banking sector. The dimension that through strategic marketing, banks have the capability to react to competiveness both local and globally after consolidation of the banking sector in 2006 compared to competitors' dimensions was ranked next with a mean score of 4.1100 and the standard deviation was .62369. The mean score for the employee voice participation dimension indicated that employees were satisfied with the degree to which they can influence decisions in their companies. The mean 
score for the competition affects strategic marketing adopted by the banks inferred that the respondents believed that competition in the banking environment influenced the strategic marketing adopted by the banks. However, the standard deviation indicated that some respondents possibly perceived competition as inevitable in the business environment and reported that influenced their organization differently.

\subsection{Test of Hypothesis}

- There is no significant influence of strategic marketing practices on the profitability in chosen Nigerian banks.

- There is a significant influence of strategic marketing practices on the profitability in chosen Nigerian banks.

The profitability in banking sector is expected to accrue on growth of the banking sector and better customer service delivery compared to competitors. The hypothesis is tested using simple linear regression analysis. The result is presented on Table 3.

Table3. Results of regression analysis with profitability of chosen banks as dependent variable and strategic marketing (SM) practices variables as independent variables

\begin{tabular}{|l|l|l|l|}
\hline Variables & Coefficients & Standard Error & Significant \\
\hline (Constant) & 1.383 & 0.291 & 0.000 \\
\hline SM Practices & 0.629 & 0.065 & 0.000 \\
\hline
\end{tabular}

$\mathrm{R}=0.701, \mathrm{R}^{2}=0.491$, Adjusted $\mathrm{R}^{2}=0.486$, t. cal $=9.676$, t. tab $=1.98 \mathrm{~F}_{(1,97)}=93.621, \mathrm{~F} . \mathrm{tab}=3.84$

From the analysis in the Table 3 , the strategic marketing practices have positive and significant influence on the profitability of the chosen Nigerian banks $\left(\beta_{1}=0.629, \mathrm{t}=9.676, \mathrm{p}=0.000\right)$. Furthermore, there is strong and positive relationship between strategic marketing practices and profitability of the chosen Nigerian banks $(r=0.701$ or $70.1 \%)$. The relationship is statistically significant because the p-value of 0.000 is less than alpha value of 0.05 . Moreover, the calculated coefficient of determination as denoted by $\mathrm{R}^{2}(0.491)$ indicated that 49.1 percent of the variation that occurs in profitability of the chosen Nigerian bank can be explained by relating it to the strategic marketing practices of the banks; with this high percentage of 49.1 percent, there is a strong indication that strategic marketing practices influenced the profitability of the chosen Nigerian bank. The adjusted $\mathrm{R}^{2}$ of $48.6 \%$ indicates that should the regression equation accommodate further explanatory variable(s), there would be a significant level of relationship among the variables. The t-calculated value $=9.676, \mathrm{p}=0.000$ is significant indicating that strategic marketing practices significantly influenced the profitability of the chosen Nigerian banks. Based on these findings, the null hypothesis which states that there is no significant influence of strategic marketing practices on the profitability in chosen Nigerian Banks is hereby rejected.

\subsection{Discussion of Findings}

The finding of this study revealed that there is significant influence of strategic marketing practices on the profitability in chosen Nigerian Banks. This is in-line with the empirical findingsof Jagersma (2003) that effective strategic marketing is a very key area to improve the overall profitability of banks, and enables banks to understand and respond to the investment nature or behavior of their customers using such strategies as segmentation. The result was also consistent with the arguments of Pride and Ferron (1987) that organizations are likely to survive competition as long as revenue and sales continue to increase. The work ofEkerete (2005) can also be said to have corroborated the findings of this work. He examined the marketing of financial services a case study of selected merchant banks in Nigeria using Spearman rank correlation coefficient and Kendall coefficient of concordance. His findings showed that there was a significant relationship between Nigerian merchant banks marketing budget and their profitability. There is also agreement among Nigerian merchant banks on the ranking of factors that shape their marketing strategies. In contrast, Ogunleye (1995) had a contrary view on strategic marketing and profitability, he contended that profit level did not measure profitability in the banking sector, and as such, employed return on equity (ROE) and return on assets (ROA). Also Akinshulire (2005) stated that for an organization to have increase in profits as a result of its strategic marketing activities, it might lead to shortage of its liquid assets (i.e. assets that can be quickly converted into cash like bonds, stocks, and so on). Therefore, to have more liquid assets in 
organization, the profitability objectives needed to be foregone. However, despite these criticisms on profitability in the Nigerian banking sector, the researchers opined that the essence of any business endeavor is profitability, which is the determinant of the continuity or discontinuity of the business that also applies to the banking sector.

\section{CONCLUSION AND RECOMMENDATIONS}

There is no doubt that banks exist in every country in the globe to provide individuals, government, and businesses financial services. To achieve this objective, the Nigerian banking sector needed to be strategically positioned to optimize opportunities in the industry. This study elaborated on strategic marketing as one of the major keys to success of banks' marketing efforts, especially, in this era of increasing competition, dynamic nature of business and economic system to achieve, and sustain competitive advantage.

Moreover, to overcome its financial distress, the Nigerian banking sector needed to be repositioned both locally and internationally; the regulatory body needed to put in place efficient regulatory framework to supervise the activities of banks. In addition, regulatory agency must ensure compliance with prevalent international standard practice in the banking sector. Above all, the banking sector should embrace strategic marketing by being focused to adapt to changes, marketing of assets and capabilities and marketing of innovation for the growth and survival of the industry.

In the process of estimation and analysis of data, profitability in the Nigerian banking sector is positively and significantly related with the strategic marketing practices. The chosen Nigerian banks faced strong business competition that affects strategic marketing adopted by the banks. In addition, strategic marketing adopted by the banks had contributed to increase in net profit, return on return on sales of chosen Nigerian banks, among others. Finally, from the result of the data collected and analyzed, the study concluded that there was a relationship between strategic marketing practices in the Nigerian banking sector and organizational performance. The findings of this research work had brought various managerial implications for the Nigerian banking sector. First, the Nigerian banking sector managers were encouraged to regularly emphasis on the embracement of various marketing strategies with the application of information technology (IT). The clearest instance for the embracement of IT that brought the growth of a firm is the banking sector, where due to IT products in information exchanges, Internet banking, security investments, and electronic payments banks can offer various services to their customers with less human resource (Aremu, Majabi, \&Gbadeyan, 2011). Presently, customers in Nigeria are capable of reaching their account anytime of the day even after they have closed from their work to withdraw money to carter for their pressing needs and wants. Second, the strategic marketing practices of banks have a crucial role in the achievement of goals and objectives of bank to sustain competitive advantage in this turbulence environment. As a result of strategic marketing in the Nigerian banking sector, many Nigerian banks play pivot roles in the world financial market with many of them rated among top 50 banks in Africa. Third, as the Nigerian banking sector operates in external environment that is dynamic, changes in the business environment might result to opportunities and threats to the banking sector; and thus affect banks' strategic operation that might not be static. The environment of business and its strategy have been theorized and demonstrated empirically to have significant impacts on organizational performance (Porter, 1982). It is therefore necessary for the Nigerian banking sector to continually monitor its environment to develop strategies necessary to deliver superior value and sustain competitive advantage. Fourth, there is the need to employ Japanese management technique whereby the strategic direction of business (including the banking sector) are not being set by the management of an organization, but every member of the firm involved in decision making. Regular checks and balances are necessary to discover compliance with the strategic marketing practices variables, as well as to deliver a better service and thus better performance in the banking sector. Finally, from the researcher's findings, it was assumed that strategic marketing practice would assist in market-driven banking operations whereby banking staff are regularly trained to compete with well-established banks in the developed nations of the world.

The study recommended that the Nigerian banking sector needs to be consistently and strategically fashioned to start positive change to take advantage of the information and communication technology (ICT) to optimize opportunities in the industry to achieve and sustain competitive advantage both within and outside the shores of Nigeria. Also, management of the Nigerian banking sector is required 
to adopt new ways of performing an activity that has never been attempted before which will give the sector an edge over its competitors (the concept of total quality management).

\subsection{Recommendations for Further Research}

In this research, the researchers approached the topic largely from the point of view of the banks. It may be interesting to get to know the point of view of the customers. Indeed, the perceived strategic marketing practices may differ completely from the marketing strategy anticipated by the banks. Thus, future research could investigate effect of strategic marketing practices by banks on customers' patronage/loyalty. Also, this research work could be investigated in other nations of the world, especially, in developing nations that have similar problems so that right decisions could be made on the concept of strategic marketing as it affects banks performance on chosen Nigerian banks.

\section{REFERENCES}

[1] Atiku, S.O., Genty, K. I., \&Akinlabi, B. H. (2011). Effects of electronic banking on employees' job security in Nigeria. European Journal of Humanities and Social Sciences,4(2), 28-41.

[2] Ojo, G. K. (2011). Effective marketing strategies and the Nigerian construction professionals. African Journal of Marketing Management, 3 (12), pp. 303-311.

[3] Oloko, M., Anene, E. B., Kiara, P. G., Kathambi, I., \&Mutulu, J. (2014). Marketing strategies for profitability: A case of Safaricom Ltd in Kenya telecommunication industry.International Journal of Scientific and Research Publications, 4(5), 1-5.

[4] Oseyomon, E. P., \&Gbandi, E. C. (2014). Market orientation and profitability of quoted companies in Nigeria. IOSR Journal of Business and Management (IOSR-JBM), 16 (6),8-24.

[5] Jenkins, W. Y. (2015). Marketing strategies for profitability in small independent restaurants. Published Dissertation Walden University.

[6] Bello, A., \&Aina, O. K. (2015). The role of marketing research on the performance of business organizations.European Journal of Business and Management, 7(6), 148-156.

[7] Ayedun, C. A., Oloyede, S. A., Oluwunmi, A. O., \&Oyedele, M. O. (2014). The effect of marketing strategies on corporate performance of estate surveying and valuation firms in Kaduna Metropolis of Nigeria. American International Journal of Social Science, 3 (4), 202-209.

[8] Chiliya, N., Herbst, G., \& Robert-Lombard, M. (2009). The impact of marketing strategies on profitability ofsmall grocery shops in South African townships.African Journal of Business Management, 3(3), 70-79.

[9] Danjuma, N. H., Audu, A. A., \&Omaku, A. A. (2014). An evaluation of marketing strategies undertaken by Coca Cola Company as a multinational corporation in Nigeria. Journal of Economics and Finance, 3 (2), 5-10.

Citation: Onu, Christopher. "The Influence of Strategic Marketing Practices on Deposit Money Banks Profitability in Nigeria" International Journal of Managerial Studies and Research (IJMSR), vol 6, no. 1, 2018, pp. 21-35. doi:http://dx.doi.org/10.20431/2349-0349.0601004.

Copyright: (1) 2018 Authors. This is an open-access article distributed under the terms of the Creative Commons Attribution License, which permits unrestricted use, distribution, and reproduction in any medium, provided the original author and source are credited. 